\title{
Metabolic Alterations Associated with $\gamma$-Hydroxybutyric Acid and the Potential of Metabolites as Biomarkers of Its Exposure
}

\author{
Suryun Jung ${ }^{1}$, Suji Kim $^{1,2}$, Yujin Seo ${ }^{1}$ and Sooyeun Lee ${ }^{1,2, * \mathbb{D}}$ \\ 1 College of Pharmacy, Keimyung University, 1095 Dalgubeoldaero, Dalseo-gu, Daegu 42601, Korea; \\ susu73@kmu.ac.kr (S.J.); kimsuji921@naver.com (S.K.); syj653@naver.com (Y.S.) \\ 2 Center for Forensic Pharmaceutical Science, Keimyung University, 1095 Dalgubeoldaero, Dalseo-gu, \\ Daegu 42601, Korea \\ * Correspondence: sylee21@kmu.ac.kr; Tel.: +82-53-580-6651; Fax: +82-53-580-5164
}

check for updates

Citation: Jung, S.; Kim, S.; Seo, Y.; Lee, S. Metabolic Alterations Associated with $\gamma$-Hydroxybutyric Acid and the Potential of Metabolites as Biomarkers of Its Exposure. Metabolites 2021, 11, 101. https:// doi.org/10.3390/metabo11020101

Academic Editor: Markus R. Meyer

Received: 27 December 2020

Accepted: 8 February 2021

Published: 10 February 2021

Publisher's Note: MDPI stays neutral with regard to jurisdictional claims in published maps and institutional affiliations.

Copyright: (c) 2021 by the authors. Licensee MDPI, Basel, Switzerland. This article is an open access article distributed under the terms and conditions of the Creative Commons Attribution (CC BY) license (https:// creativecommons.org/licenses/by/ $4.0 /)$.

\begin{abstract}
Hydroxybutyric acid (GHB) is an endogenous short chain fatty acid that acts as a neurotransmitter and neuromodulator in the mammalian brain. It has often been illegally abused or misused due to its strong anesthetic effect, particularly in drug-facilitated crimes worldwide. However, proving its ingestion is not straightforward because of the difficulty in distinguishing between endogenous and exogenous GHB, as well as its rapid metabolism. Metabolomics and metabolism studies have recently been used to identify potential biomarkers of GHB exposure. This mini-review provides an overview of GHB-associated metabolic alterations and explores the potential of metabolites for application as biomarkers of GHB exposure. For this, we discuss the biosynthesis and metabolism of GHB, analytical issues of GHB in biological samples, alterations in metabolic pathways, and changes in the levels of GHB conjugates in biological samples from animal and human studies. Metabolic alterations in organic acids, amino acids, and polyamines in urine enable discrimination between GHB-ingested animals or humans and controls. The potential of GHB conjugates has been investigated in a variety of clinical settings. Despite the recent growth in the application of metabolomics and metabolism studies associated with GHB exposure, it remains challenging to distinguish between endogenous and exogenous GHB. This review highlights the significance of further metabolomics and metabolism studies for the discovery of practical peripheral biomarkers of GHB exposure.
\end{abstract}

Keywords: $\gamma$-hydroxybutyrate; drugs of abuse; drug-facilitated crimes; metabolomics

\section{Introduction}

Metabolomics is a field of omics science that investigates changes in metabolites with molecular weights of $1500 \mathrm{Da}$ or less in biological samples and aims to understand metabolic pathways related to abnormal conditions or diseases. It is used to discover biomarkers that can serve as indicators of normal and pathological processes or reactions upon exposure to drugs, toxicants, or any intervention [1,2]. Analytical methods, including gas chromatography-mass spectrometry (GC-MS), liquid chromatography-mass spectrometry (LC-MS), nuclear magnetic resonance (NMR), and capillary electrophoresis-mass spectrometry (CE-MS), are used to investigate alterations in the concentrations of metabolites in a variety of biological samples such as blood, urine, and hair. In general, MS offers the advantage of displaying high sensitivity and a wide detection range, while NMR allows for non-destructive and minimal sample preparation [2,3]. Plasma and serum samples provide much information on physiological and pathological conditions in a particular biological system, over a short period of time [4]. Since many biogenic products eventually find their way to the urine, urinary metabolites are very beneficial for understanding the condition of diseases. Owing to the simple and noninvasive sampling process, the presence of metabolites in large quantities, and the extended detection window, urine is considered an ideal sample compared to plasma and serum for biomarker monitoring in clinical 
analyses [5,6]. Among biological samples, hair is more recently being used to monitor chronic drug use or chronic diseases, because it provides long detection windows, and segmental analysis of hair reflects the toxicological or pathological history [7]. Analytical approaches for metabolomics include targeted and untargeted analyses. Targeted analysis investigates metabolic changes based on physicochemically similar metabolomes (e.g., carbohydrates, amino acids (AAs), organic acids (OAs), nucleosides) or biochemical (e.g., glycolysis, gluconeogenesis, $\beta$-oxidation, or citric acid cycle) and metabolic (e.g., phase-I and -II metabolism) pathways. Therefore, selective and sensitive sample preparation methods and optimized analytical techniques are necessary for evaluating selected metabolites. Untargeted analysis is a method for analyzing the overall metabolic change in a selected biological sample, based on extensive information on unknown features, followed by the assignment of significantly altered features to specific metabolites. To investigate the maximum number of metabolites possible, non-selective approaches have been adopted for sample preparation and instrumental analysis [2,4]. In particular, metabolomics is currently being used to identify endogenous metabolites generated after exposure to addictive drugs [8-11]. This metabolomics approach can provide a new foundation for identifying effective diagnostic markers or therapeutic targets, if the knowledge of the mechanisms of a drug's pharmacodynamic or pharmacokinetic properties is limited [12].

$\gamma$-Hydroxybutyric acid (4-hydroxybutyric acid, GHB, m.w. $104.1 \mathrm{~g} / \mathrm{mol}$ ) is a naturally occurring short-chain fatty acid in the human brain that acts as a neurotransmitter and neuromodulator [13]. GHB was developed as an anesthetic in the 1960s; however, its use was limited thereafter due to the occurrence of pain and delirium [14]. It is currently being used to treat Excessive Daytime Sleepiness (EDS) and cataplexy $\left(\mathrm{Xyrem}^{\circledR}\right.$; sodium oxybate) in patients with narcolepsy-with doses ranging from 3.0 to $9.0 \mathrm{~g}$ and treatment lasting from 4 to 8 weeks [15] —and for alcohol dependence and withdrawal (Alcover ${ }^{\circledR}$ ) in Austria and Italy. However, as with other psychotropic drugs, there is a high risk of side effects upon GHB abuse, so its use other than for treatment of disease is strictly prohibited. Ingestion of GHB in recreational doses $(>10 \mathrm{mg} / \mathrm{kg}$ ) relieves tension, induces euphoria, and increases sexual pleasure. However, ingestion of $20-30 \mathrm{mg} / \mathrm{kg}$ of GHB can lead to dizziness, drowsiness, nausea, and vomiting, while intake of GHB over $50 \mathrm{mg} / \mathrm{kg}$ can lead to coma and death $[16,17]$. Moreover, people intoxicated with GHB may suffer from anterograde amnesia, which is one of the reasons criminals use this drug in sexual assault cases [18]. Possible withdrawal symptoms post GHB use include mild tremor, tachycardia, high blood pressure, anxiety, agitation, seizures, insomnia, severe disorientation, hallucinations, delirium, and rhabdomyolysis [19]. The average self-administration dose reported in dependent patients ranged from 32 to $67.2 \mathrm{~g} /$ day [20] to a maximum of $144 \mathrm{~g} /$ day [21] at 45-min to 2.5-h intervals. The severity of physical dependence on GHB is affected by the dose and duration of abuse [22], and high doses and/or long-term administration may be important factors influencing the physical dependence on GHB [23]. To date, a number of studies have been conducted to develop a therapeutic agent to reverse GHBinduced intoxication and sedative effects. Representatively, physostigmine has shown the possibility of recovering the GHB-induced change in consciousness state [24,25]. However, physostigmine increases cardiovascular-related side effects [26], while naloxone [27], an opiate antagonist, and flumazenil [28], a selective benzodiazepine receptor antagonist, have not been found to be effective in reversing the sedative effects of GHB. Upon studying whether the $\gamma$-aminobutyric acid (GABA)-B receptor antagonist has an effect on reducing mortality due to excessive GHB intake in mice, no significant effect was found [29]. Taken together, there is no antidote for GHB intoxication; in addition, the gap between the recreational and lethal doses of GHB is narrow, resulting in frequent accidental overdose deaths [30,31]. Therefore, various studies need to be carried out in clinical and forensic areas to diagnose and treat GHB poisoning and addiction. This review summarizes the methods and results of such studies, while focusing on studies of exogenous GHB (ExGHB) exploration using metabolomics or metabolite analysis, in addition to providing the latest information on the biomarkers of ExGHB. With specific focus on research publications 
from January 2010 till September 2020, a search was conducted in PubMed using the following keywords: [" $\gamma$-hydroxybutyric acid," " $\gamma$-hydroxybutyrate," or "GHB"] and ["metabolomics" or "metabolites"]. A total of 222 papers were searched with the keywords, and 25 papers were selected, excluding those with duplicate and low accuracy. Among them, 10 articles [32-41] were selected and analyzed after the exclusion of 14 papers. The exclusion criteria were as follows: reviews $(n=2)$ and purpose different from that of the current study (e.g., plant, succinic semialdehyde dehydrogenase deficiency, among others; $n=12$ ). Additionally, one article [42] found in the reference list in one [34] of the searched articles was included since it is a metabolomics study of GHB.

\section{Biosynthesis and Metabolism of GHB}

Figure 1 illustrates the biosynthesis and metabolism of GHB and the potential biomarkers for GHB exposure. In the human brain, GHB (endogenous GHB; EnGHB) is produced from GABA by the action of GABA aminotransferase and succinic semialdehyde reductase. EnGHB concentration is the highest in the striatum, about 11-25 $\mu \mathrm{M}$ [43], and the lowest in certain areas of the cerebellum and cerebral cortex [44]. It is also found in the heart, liver, kidney, muscle, and brown fat, but its function in these organs is still unclear [45]. The generated GHB is converted to succinic semialdehyde (SSA) and converted back to GABA [46], or is metabolized to succinic acid and removed for use in energy metabolism through the Krebs cycle [47]. In addition, a small amount of GHB that is not metabolized is excreted in the urine [17]. Since GHB exists as a physiological compound in the human body, and ExGHB exhibits the same physiological effects using almost the same neurobiological pathway as EnGHB, it is difficult to distinguish between EnGHB and ExGHB $[48,49]$.

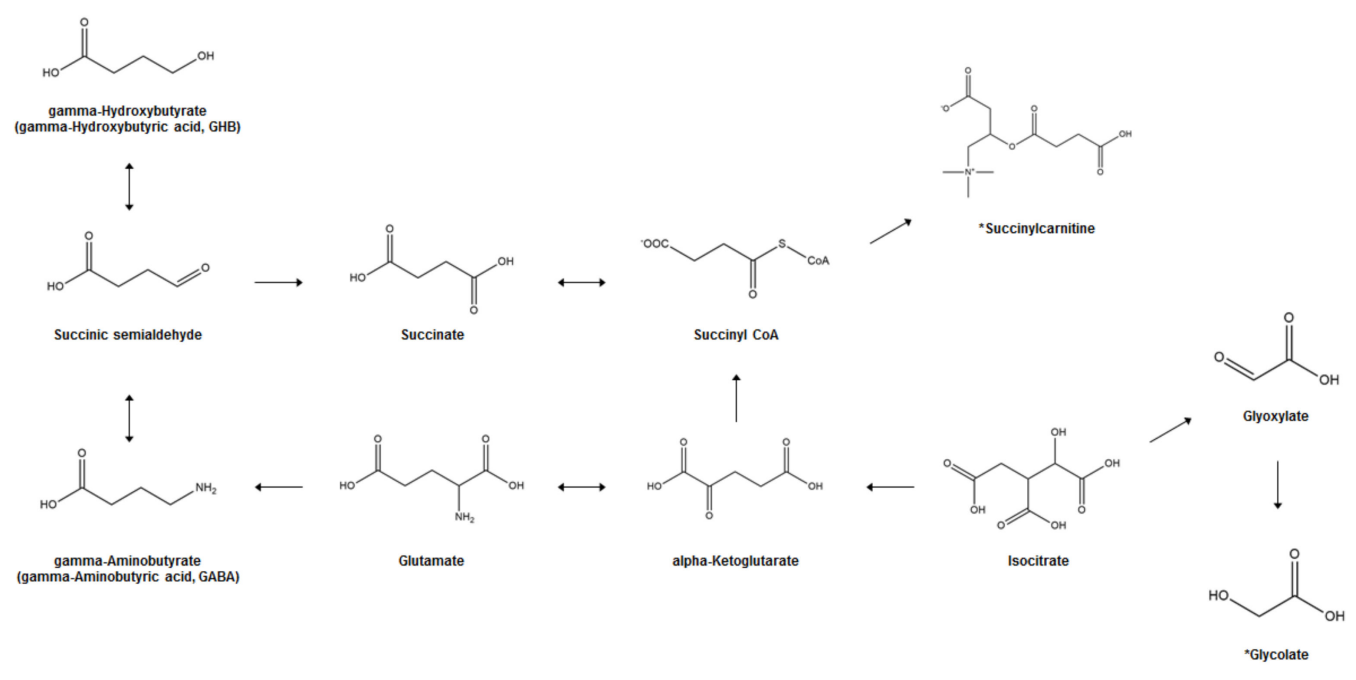

Figure 1. GHB biosynthesis and metabolism and potential biomarkers of GHB exposure. *; Proposed potential biomarker.

Another characteristic of GHB is that its metabolism occurs very quickly. A single oral intake ( $25 \mathrm{mg} / \mathrm{kg}$ body weight) of GHB in healthy adults results in the maximum plasma concentration within 30-90 $\mathrm{min}$, with an average half-life of 40-60 $\mathrm{min}$ in the plasma [50]. GHB can be detected only within $6 \mathrm{~h}$ in the blood [51] and $12 \mathrm{~h}$ in the urine [52]. Because of these metabolic properties of GHB, it is very difficult to detect GHB in human biological samples to prove abuse or drug-related crime [53]. Until now, a number of studies have suggested cut-offs for the distinction of EnGHB and ExGHB concentrations in the urine or serum/plasma, but no consensus has been reached. Currently, $6-10 \mathrm{mg} / \mathrm{L}$ in urine and at least $4 \mathrm{mg} / \mathrm{L}$ in blood are accepted as typical human ExGHB cut-off concentrations [54-56]. However, some studies suggest a cut-off concentration of $1 \mathrm{mg} / \mathrm{L}$ in blood [57] and $5 \mathrm{mg} / \mathrm{L}$ [58,59] or $2 \mathrm{mg} / \mathrm{L}$ [60] in urine. Andresen et al. [61] collected blood and urine samples from 50 subjects who had never ingested GHB and analyzed them using GC-MS. The concentration of GHB ranged from 
$0.62-3.24 \mathrm{mg} / \mathrm{L}$ (mean $=1.14 \mathrm{mg} / \mathrm{L}$ and median $=0.97 \mathrm{mg} / \mathrm{L}$ ) in serum and $0.64-4.20 \mathrm{mg} / \mathrm{L}$ $($ mean $=1.21 \mathrm{mg} / \mathrm{L}$, median $=0.96 \mathrm{mg} / \mathrm{L})$ in urine. Based on these results, it was suggested that the use of $6 \mathrm{mg} / \mathrm{L}$ for the urine GHB cut-off value instead of $10 \mathrm{mg} / \mathrm{L}$ is appropriate to avoid false negative interpretation. In addition, Kang et al. [62] reported that $0.09-1.8 \mathrm{~g} / \mathrm{mL}$ of GHB was detected in the urine of 79 healthy volunteers, and when this concentration was adjusted to the creatine concentration, $4.5-530 \mathrm{~g} / \mathrm{mmol}$ of GHB was present. Sex and age, but not smoking, alcohol, or caffeine intake, have been reported to have an effect on the concentration of EnGHB in urine. Despite the fact that multiple studies and discussions have been published on the cut-off level for GHB detection in biological specimens, the application of these methods to forensic cases is not simple. There are numerous factors to be considered, such as the in vivo and in vitro production of GHB in human biological specimens depending on the post-mortem interval, the time between sampling and analysis, the sample storage conditions (e.g., storage temperature, storage period, and addition of preservatives, among others), and the concomitant use of GHB with other drugs, including ethanol [63,64]. Although unusual, the conditions of GHBuria ( $\gamma$-Hydroxybutyric aciduria) and succinic semialdehyde dehydrogenase deficiency (SSADH-D) should also be considered during diagnosis. SSADH-D is a disease caused by a mitochondrial enzyme that results in abnormal metabolism of the neurotransmitter GABA, leading to accumulation of GABA and GHB in the body, while GHBuria is a rare genetic disease characterized by the excretion of accumulated excess GHB in the urine [65]. Increased endogenous GABA and GHB levels through SSADH-D contribute to neurological disorders such as cognitive deficit and speech impairment, ataxia, hypotension, decreased reflexes, behavioral dysregulation, and compulsion [66].

\section{Analytical Issues of GHB in Biological Samples}

For forensic toxicological purposes in drug-facilitated crimes or post-mortem cases, biological samples such as urine $[55,58,67,68]$, saliva $[69,70]$, vitreous humor [71-73], blood spots [74,75], and hair [76-78] have often been analyzed using GC-MS or LC-MS, with or without chemical derivatization. However, the accurate quantification of GHB in biological samples is complicated because of the absence of an analyte-free matrix and the endogenous presence of GHB isomers, such as beta-hydroxybutyrate and alpha-hydroxybutyrate, the concentrations of which increase in diabetics [79]. In previous studies, quantification of urinary GHB was performed using water [68,80] or synthetic urine [81] as an analyte-free matrix and ${ }^{2} \mathrm{H}_{6}$-GHB as a surrogate standard together with ${ }^{13} \mathrm{C}_{2}$-dl-3-hydroxybutyrate as an internal standard [62]. Missing matrix-matched calibrators is considered complex because parallelism between the alternative analyte-free matrix and the authentic matrix or surrogate and original standards needs to be confirmed before their use.

Another critical issue in the analysis of GHB in biological samples is the in vitro production of GHB under sample storage conditions (e.g., temperature, period, addition of preservatives, etc.). Nevertheless, the stability of GHB has been only partially or not investigated during method validation in many previous studies [68,82-84]. In previous studies, EnGHB was stable in blood or urine at $-20^{\circ} \mathrm{C}$ with fluoride preservation, while an increase in GHB was observed at a higher temperature $\left(4^{\circ} \mathrm{C}\right)$ and/or without preservatives $[67,85]$. In another study, the concentration of EnGHB increased by greater than 2-fold at $4{ }^{\circ} \mathrm{C}$ for 7 or 14 days and to more than $110 \%$ at $-20{ }^{\circ} \mathrm{C}$ for 7 or 14 days. EnGHB was stable only at $-80^{\circ} \mathrm{C}$ for 7 or 14 days [62].

\section{GHB-Associated Metabolic Changes in AA, OA, and Polyamine (PA)}

Table 1 summarizes metabolomics studies performed to investigate metabolic changes following GHB exposure in the urine of rats or humans [32-34,42]. GHB-associated metabolic changes in animal studies [32,34,42] were further confirmed in a clinical setting [33]. To perform the targeted metabolic profiling of AA, OA, and PA in rat urine, chemical derivatization was conducted for specific functional groups followed by GC-MS analysis. For untargeted metabolomics using NMR, human urine was lyophilized and reconstituted in $\mathrm{D}_{2} \mathrm{O}$. 
Table 1. Summary of metabolic changes in organic acids, amino acids, and polyamines following GHB exposure.

\begin{tabular}{|c|c|c|c|c|c|c|c|}
\hline $\begin{array}{l}\text { Reference } \\
\text { No. }\end{array}$ & Sample & Sample Preparation & $\begin{array}{l}\text { Analytical Platform } \\
\text { (Untargeted } \\
\text { or Targeted) }\end{array}$ & $\begin{array}{c}\text { Treatment } \\
\text { (Administration Dose, } \\
\text { Route, and No. } \\
\text { of Doses) }\end{array}$ & Sampling Time & Metabolic Changes & Summary \\
\hline \multirow{2}{*}{ [42] } & \multirow{2}{*}{$\begin{array}{l}\text { Male SD rat } \\
(n=18), \text { urine }\end{array}$} & \multirow{2}{*}{$\begin{array}{l}\text { Methoxime/tert- } \\
\text { butyldimethylsilyl } \\
\text { derivatization }\end{array}$} & \multirow{2}{*}{ GC-SIM-MS(targeted) } & \multirow{2}{*}{$\begin{array}{l}600 \mathrm{mg} / \mathrm{kg} \text { GHB, i.p. } \\
\text { once per day for } 10 \text { days }\end{array}$} & $\begin{array}{c}\text { For } 12 \mathrm{~h} \text { following } \\
\text { single } \\
\text { administration }\end{array}$ & $\begin{array}{c}\text { Pyruvic acid }(\uparrow) \text {, acetoacetic acid }(\downarrow) \text {, lactic acid } \\
(\uparrow) \text {, glycolic acid }(\uparrow), 2 \text {-hydroxybutyric acid }(\downarrow) \text {, } \\
\text { malonic acid }(\downarrow) \text {, succinic acid }(\uparrow) \text {, fumaric acid } \\
(\uparrow) \text {, oxaloacetic acid }(\uparrow) \text {, malic acid }(\uparrow) \text {, } \\
\alpha \text {-ketoglutaric acid }(\uparrow), 2 \text {-hydroxyglutaric acid } \\
(\uparrow) \text {, cis-aconitic acid }(\uparrow) \text {, citric acid }(\uparrow) \text {, isocitric } \\
\text { acid }(\uparrow), \gamma \text {-hydroxybutyric acid }(\uparrow)\end{array}$ & \multirow{2}{*}{$\begin{array}{c}\text { Alteration of organic } \\
\text { acid metabolism related } \\
\text { with tricarboxylic acid } \\
\text { cycle } \\
\text { Key metabolite: } \\
\text { 2-hydroxyglutaric acid }\end{array}$} \\
\hline & & & & & $\begin{array}{c}\text { For } 12 \mathrm{~h} \text { following } \\
\text { multiple } \\
\text { administration } \\
(10 \text { times })\end{array}$ & $\begin{array}{c}\text { Pyruvic acid }(\uparrow) \text {, acetoacetic acid }(\uparrow) \text {, lactic acid } \\
(\uparrow) \text {, glycolic acid }(\uparrow), 2 \text {-hydroxybutyric acid }(\uparrow) \text {, } \\
\text { malonic acid }(\uparrow) \text {, succinic acid }(\uparrow) \text {, fumaric acid } \\
(\uparrow) \text {, oxaloacetic acid }(\uparrow) \text {, malic acid }(\uparrow) \text {, } \\
\alpha \text {-ketoglutaric acid }(\uparrow), 2 \text {-hydroxyglutaric acid } \\
(\uparrow) \text {, cis-aconitic acid }(\uparrow) \text {, citric acid }(\uparrow) \text {, isocitric } \\
\text { acid }(\uparrow), \gamma \text {-hydroxybutyric acid }(\uparrow)\end{array}$ & \\
\hline \multirow[t]{2}{*}{ [34] } & \multirow[t]{2}{*}{$\begin{array}{l}\text { Male SD rat } \\
(n=25), \text { urine }\end{array}$} & \multirow[t]{2}{*}{$\begin{array}{l}\text { Ethoxycarbonyl/tert- } \\
\text { butyldimethylsilyl } \\
\text { derivatization }\end{array}$} & \multirow[t]{2}{*}{ GC-SIM-MS(targeted) } & \multirow[t]{2}{*}{$\begin{array}{l}600 \mathrm{mg} / \mathrm{kg} \mathrm{GHB} \text {, i.p. } \\
\text { once per day for } 10 \text { days }\end{array}$} & $\begin{array}{c}\text { For } 12 \mathrm{~h} \text { following } \\
\text { single } \\
\text { administration }\end{array}$ & $\begin{array}{c}\text { Alanine }(\uparrow) \text {, glycine }(\uparrow), \alpha \text {-aminobutyric acid }(\uparrow) \text {, } \\
\text { valine }(\uparrow), \beta \text {-aminoisobutyric acid }(\uparrow), \text { leucine, } \\
\text { isoleucine }(\uparrow) \text {, serine }(\uparrow) \text {, proline }(\uparrow) \text {, } \\
\gamma \text {-aminobutyric acid }(\uparrow) \text {, pipecolic acid }(\uparrow), \\
\text { 4-hydroxyproline }(\uparrow) \text {, methionine }(\uparrow) \text {, } \\
\text { phenylalanine }(\uparrow) \text {, aspartic acid }(\uparrow) \text {, glutamic acid } \\
(\uparrow) \text {, asparagine }(\uparrow) \text {, ornithine }(\uparrow) \text {, lysine }(\uparrow) \text {, } \\
\text { histidine }(\uparrow) \text {, tyrosine }(\uparrow), \text { tryptophan }(\uparrow), \\
\text { glutamine }(\downarrow)\end{array}$ & \multirow{2}{*}{$\begin{array}{l}\text { Alteration of amino acid } \\
\text { metabolism } \\
\text { Key metabolite(s): } \\
\text { phenylalanine, glutamic } \\
\text { acid, aspartic acid, } \\
\text { asparagine, and } \\
\text { methionine }\end{array}$} \\
\hline & & & & & $\begin{array}{c}\text { For } 12 \mathrm{~h} \text { following } \\
\text { multiple } \\
\text { administration } \\
\text { (10 times })\end{array}$ & $\begin{array}{l}\text { Leucine }(\uparrow) \text {, isoleucine }(\uparrow) \text {, serine }(\uparrow) \text {, proline }(\uparrow) \text {, } \\
\text { histidine }(\downarrow) \text {, phenylalanine }(\downarrow), \gamma \text {-aminobutyric } \\
\text { acid }(\uparrow) \text {, pyroglutamic acid }(\uparrow), \alpha \text {-aminoadipic } \\
\text { acid }(\uparrow) \text {, glycine }(\downarrow) \text {, methionine }(\downarrow) \text {, tyrosine }(\downarrow) \\
\text { 4-hydroxyproline }(\downarrow) \text {, aspartic acid }(\downarrow) \text {, glutamic } \\
\text { acid }(\downarrow) \text {, asparagine }(\downarrow) \text {, ornithine }(\downarrow) \text {, glutamine } \\
(\downarrow) \text {, lysine }(\downarrow)\end{array}$ & \\
\hline
\end{tabular}


Table 1. Cont.

\begin{tabular}{|c|c|c|c|c|c|c|c|}
\hline $\begin{array}{l}\text { Reference } \\
\text { No. }\end{array}$ & Sample & Sample Preparation & $\begin{array}{l}\text { Analytical Platform } \\
\text { (Untargeted or } \\
\text { Targeted) }\end{array}$ & $\begin{array}{c}\text { Treatment } \\
\text { (Administration Dose, } \\
\text { Route, and No. of } \\
\text { Doses) }\end{array}$ & Sampling Time & Metabolic Changes & Summary \\
\hline \multirow[b]{2}{*}{ [32] } & \multirow{2}{*}{$\begin{array}{l}\text { Male SD rat } \\
(n=18), \text { urine }\end{array}$} & \multirow{2}{*}{$\begin{array}{l}\text { N-ethoxylcarbonyl-N- } \\
\text { pentafluoropropionyl } \\
\text { derivatization }\end{array}$} & \multirow[b]{2}{*}{ GC-SIM-MS(targeted) } & \multirow{2}{*}{$\begin{array}{l}600 \mathrm{mg} / \mathrm{kg} \text { GHB, i.p. } \\
\text { once per day for } 10 \text { days }\end{array}$} & $\begin{array}{l}\text { For } 12 \mathrm{~h} \text { following } \\
\text { single } \\
\text { administration }\end{array}$ & $\begin{array}{c}\text { Putrescine }(\uparrow), \\
\mathrm{N}^{1} \text {-acetylspermidine }(\uparrow) \text {, spermine }(\uparrow) \text {, } \\
\mathrm{N}^{1} \text {-acetylspermine }(\uparrow)\end{array}$ & \multirow{2}{*}{$\begin{array}{l}\text { Alteration of polyamine } \\
\text { metabolism } \\
\text { Key metabolite(s): } \\
\text { N1-acetylspermine and } \\
\text { spermine }\end{array}$} \\
\hline & & & & & $\begin{array}{l}\text { For } 12 \mathrm{~h} \text { following } \\
\text { multiple } \\
\text { administration } \\
\text { (10 times) }\end{array}$ & $\begin{array}{c}\text { Putrescine }(\downarrow), \\
\mathrm{N}^{1} \text {-acetylspermidine }(\downarrow) \text {, spermine }(\uparrow) \text {, } \\
\mathrm{N}^{1} \text {-acetylspermine }(\uparrow)\end{array}$ & \\
\hline [33] & $\begin{array}{l}\text { Healthy men \& } \\
\text { women ( } n=12, \\
\text { each), urine }\end{array}$ & $\begin{array}{l}\text { Lyophilization and } \\
\text { reconstitution in } \mathrm{D}_{2} \mathrm{O}\end{array}$ & NMR(untargeted) & $\begin{array}{c}25 \mathrm{mg} / \mathrm{kg} \mathrm{GHB} \\
\left(\text { Xyrem }^{\circledR}\right)\end{array}$ & $\begin{array}{l}\text { Urine: } 10 \mathrm{~min}, 1,2, \\
4,6,14,20,24, \text { and } \\
30 \mathrm{~h} \text { post dose }\end{array}$ & $\begin{array}{l}\text { Glycolate }(\uparrow) \\
\text { succinate }(\uparrow)\end{array}$ & $\begin{array}{c}\text { Confirmation of } \\
\text { glycolate and succinate } \\
\text { as potent markers for } \\
\text { GHB, Slower } \\
\text { elimination of glycolate } \\
\text { (even after } 24 \mathrm{~h} \text { ) than } \\
\text { succinate (at time point } \\
\text { of } 6 \mathrm{~h} \text { ) }\end{array}$ \\
\hline
\end{tabular}

GC, gas chromatography; SIM, selected ion monitoring; MS, mass spectrometry; i.p., intraperitoneal injection; $\uparrow$, significantly increased vs. vehicle group; $\downarrow$, significantly decreased vs. vehicle group. 
A previous study demonstrated the accumulation of D-2-hydroxyglutaric acid (D-2$\mathrm{HG}$ ) in blood and urine from baboons following GHB exposure, based on the hypothesis of conversion of GHB to D-2-HG, a reaction catalyzed by d-2-hydroxyglutarate transhydrogenase [86]. In the intermediate metabolic pathway, various OAs such as mono-, di-, and tri-carboxylic acids with hydroxyl, aromatic rings, and carbonyl groups as metabolites are involved in the metabolism of AAs as well as the tricarboxylic acid (TCA) cycle and $\beta$-oxidation of fatty acids. According to previous studies, changes in OA levels are reported in the conditions of diabetes [87], cancer [88] and genetic metabolic disorders [89,90]. An animal study was performed to study the effect of GHB administration for 1 or 10 days (600 mg/kg, i.p., once/day) on TCA cycle-related OA and D-2-HG levels in rats using GC-MS analysis. The results showed that single or multiple doses of GHB increased most of the OA, including GHB and D-2-HG, in the urine of rats $(p<0.05)$; in addition, the single dose group showed a greater increase in these factors than the multiple dose group. From these results, it was concluded that citrate, isocitrate, and cis-aconitate profiling are useful biomarkers for discriminating GHB intoxication [42]. AAs are precursors and products of OAs that are closely related to GHB metabolism and the TCA cycle; AA in the blood gets excreted into urine to maintain homeostasis. Therefore, profiling of AAs using urine samples is very useful for monitoring altered metabolism and understanding biochemical changes [90,91]. Seo et al. [34] profiled AAs, including GABA and glutamic acid, using GC-MS after GHB administration (600 mg/kg, i.p., once/day) to rats for 1 or 10 days. They found that 28 AAs were detected in urine in the control and GHB-intake groups at levels exceeding the limit of quantification of the AA profiling method. In addition, levels of GABA and glutamic acid, which are GHB metabolites, were significantly higher in the urine of the single treatment group. In addition, it has been reported that phenylalanine, glutamic acid, aspartic acid, asparagine, and methionine are metabolites that can help in distinguishing whether or not GHB has been taken and the number of doses. These results suggest that changes in AA metabolism could be used as a useful biomarker for discriminating GHB administration. PA is being studied with a focus on cell growth, cell proliferation, protein, and nucleic acid synthesis by controlling its acetylation-deacetylation, according to changes in biochemical conditions [92-94]. Recently, studies on PA have focused on its role in a PA-mediated stress response signaling system and as a marker for monitoring and diagnosing various disease states [95-97]. Therefore, endogenous PA profile analysis is important for understanding biochemical changes post GHB exposure. Accordingly, Lee et al. [32] administered GHB (600 mg/kg, i.p., once/day) to rats for 1 or 10 days and then profiled PA in the urine using GC-MS. The levels of $\mathrm{N}^{1}$-acetylspermine, putrescine, $\mathrm{N}^{1}$-acetylspermidine, and spermine were found to be significantly higher in the single administration group, as compared to the control group, but the levels of putrescine and $\mathrm{N}^{1}$-acetylspermidine were found to be significantly lower in the multiple administration group. In summary, there were significant differences in the levels of $\mathrm{N}^{1}$-acetylspermine between the three groups, while the levels of spermine differed significantly between the administered and non-administered groups. Therefore, $\mathrm{N}^{1}$-acetylspermine and spermine have been suggested as potential biomarkers of GHB exposure and poisoning.

Although little metabolomics studies have been conducted on clinical settings, the elevated urinary levels of OAs, such as succinate, following GHB exposure, were observed in a previous human study [33]. Palomino-Schätzlein et al. [33] collected urine samples for $30 \mathrm{~h}$ after one dose of GHB (Xyrem ${ }^{\circledR}$, sodium oxybate, $500 \mathrm{mg} / \mathrm{L}$ ) in healthy adult men and women and analyzed them using NMR spectroscopy. There was a significant increase in the concentration of succinate and glycolate in urine post GHB administration. However, while the levels of succinate decreased rapidly, glycolate was identified as a biomarker capable of discriminating ExGHB, as it maintained a high level for more than $20 \mathrm{~h}$, as compared to the levels before GHB intake. 


\section{Changes in the Levels of GHB Conjugates upon GHB Exposure}

In recent studies, GHB-GLUC and GHB-SUL, which are phase-II-metabolites of GHB, have been considered as potential biomarkers for GHB exposure despite controversial data on their merits, such as longer detection window, compared to GHB [35,36,98,99]. A number of studies have attempted to develop and verify methods for measuring phase-IImetabolites in various biological samples, including human urine and blood (Tables 2 and 3). To selectively and sensitively quantify GHB and/or GHB conjugates in a variety of samples, such as urine, blood, nail, and hair, different sample preparation approaches, including protein precipitation, chemical derivatization, and solid phase extraction, followed by GCMS/MS or LC-MS/MS, have been employed. The baseline levels of phase-II-metabolites were measured in urine, nails, and hair in a healthy general population without GHB intake. GHB-GLUC was found to be in the range of $0.11-5.0 \mathrm{mg} / \mathrm{mL}$ in urine [36] and $0.08-0.252 \mathrm{ng} / \mathrm{mg}$ in nails [76]. As a result of measuring the EnGHB concentration in the hairs of 60 healthy adults and 5 infants, a GHB concentration of $0.11-0.96 \mathrm{ng} / \mathrm{mg}$ (average $0.38 \pm 0.25 \mathrm{ng} / \mathrm{mg}$ ) was detected in 44 samples. In addition, GHB concentrations between LOD and LOQ (0.033-0.1 ng/mg) were detected in 21 samples. However, GHB-GLUC was detected at concentrations between LOD and LOQ $(0.11-0.37 \mathrm{ng} / \mathrm{mg})$ in only three samples $(4.6 \%)$ and was not detected in the remaining samples [37]. Upon measurement of the levels in a post-mortem peripheral blood sample, $0.8-23 \mathrm{mg} / \mathrm{L}$ of GHB was detected, whereas GHB-GLUC was not detected. Hanisch et al. [35] reported that $70-170 \mu \mathrm{g} / \mathrm{mL}$ of GHB-SUL was detected in human urine in their study.

Table 2. Summary of analysis of GHB conjugates in human biological samples from non-GHB users.

\begin{tabular}{|c|c|c|c|c|}
\hline Reference No. & Sample & Sample Preparation & Analytical Platform & Concentration Range \\
\hline [36] & $\begin{array}{l}\text { Anonymous clinical } \\
\text { urine samples }(n=50)\end{array}$ & Dilution & LC-MS/MS & $\begin{array}{l}\text { GHB-GLUC, } 0.11-5.0 \mathrm{mgL} \\
\text { (mean, } 1.3 \pm 1.2 \mathrm{mgL})\end{array}$ \\
\hline [35] & $\begin{array}{l}\text { Authentic urine } \\
\text { samples }(n=5)\end{array}$ & Protein precipitation & LC-MS/MS & GHB-SUL, 70-170 mgL \\
\hline [38] & $\begin{array}{l}\text { Post-mortem } \\
\text { peripheral blood } \\
\text { samples }(n=12)\end{array}$ & $\begin{array}{l}\text { Protein precipitation } \\
\text { followed by } \\
\text { trimethylsilyl } \\
\text { derivatization }\end{array}$ & GC-MS/MS & $\begin{array}{l}\text { GHB, } 0.8-23 \mathrm{mg} / \mathrm{L} ; \\
\text { GHB-GLUC, ND }\end{array}$ \\
\hline [39] & $\begin{array}{l}\text { Healthy adults \& } \\
\text { children nail samples } \\
\qquad(n=90)\end{array}$ & $\begin{array}{l}\text { Digestion followed by } \\
\text { solid phase extraction }\end{array}$ & LC-MS/MS & $\begin{array}{c}\mathrm{GHB}, 0.3-3.8 \mathrm{ng} / \mathrm{mg} \text { in } \\
\text { fingernails and } 0.3-2.4 \mathrm{ng} / \mathrm{mg} \\
\text { in toenails; GHB-GLUC, } \\
0.08-0.252 \mathrm{ng} / \mathrm{mg} \text { in } \\
\text { fingernails }\end{array}$ \\
\hline [37] & $\begin{array}{c}\text { Healthy adults \& } \\
\text { children hair samples } \\
\qquad(n=65)\end{array}$ & Solvent extraction & LC-MS/MS & $\begin{array}{c}\text { GHB, } 0.11-0.96 \mathrm{ng} / \mathrm{mg} \text { (mean, } \\
0.38 \pm 0.25 \mathrm{ng} / \mathrm{mg}, n=44) ; \\
\text { GHB-GLUC, <LOQ }(n=3)\end{array}$ \\
\hline [40] & $\begin{array}{l}\text { Athletes }(n=100) \& \\
\text { sports students }(n=50) \\
\text { urine samples }\end{array}$ & Dilution & LC-QTOF-MS & $\begin{array}{l}\text { GHB-SUL, } 0.009-11.5 \mathrm{mgL} ; \\
\text { GHB-GLUC, } 0.5-19.8 \mathrm{mgL}\end{array}$ \\
\hline
\end{tabular}

LC-MS/MS, liquid chromatography-tandem mass spectrometry; GC-MS/MS, gas chromatography-tandem mass spectrometry; GLUC, glucuronide; SUL, sulfate; ND, not detected; <LOQ, below the limit of quantification; LC-QTOF-MS, liquid chromatography-quadrupoletime-of-flight mass spectrometry.

Piper et al. [40] measured the concentrations of GHB-conjugate in the urine of athletes $(n=100)$ and physical college students $(n=50)$. GHB-SULF concentration was 9-11,500 ng/mL and GHB-GLUC was 500-19,800 ng/mL. They used these values to calculate a preliminary reference population-based threshold and compared it to the concentration measured $72 \mathrm{~h}$ post GHB administration in urine samples from three volunteers. The results showed that GHB-SULF and GHB-GLUC were not suitable for judging GHB exposure because of the large difference in concentrations between the individuals. However, 
in the case of GHB-GLUC, there was an improvement in the reference population-based threshold upon correcting for urine-specific gravity. Accordingly, it was found that the ratio of GHB-GLUC and $\beta$-citryl glutamic acid was a promising tool to extend the possibility of GHB detection, as it was found that $\beta$-citryl glutamic acid is another compound in urine that has a significant correlation with GHB-GLUC excretion. Steuer et al. [41] conducted a randomized, placebo-controlled crossover study of 20 healthy male volunteers. Analysis of urine samples obtained $4.5 \mathrm{~h}$ post GHB administration showed significantly increased concentrations of eight compounds, including the GHB conjugates GHB-carnitine, GHBglutamate, and GHB-glycine, and endogenous compounds glycolate and succinylcarnitine. GHB-carnitine, GHB-glutamate, and GHB-glycine were detected only in the GHB intake group and not in the placebo group. However, glycolate and succinylcarnitine were detected in both the GHB-ingestion and placebo groups, but GHB exposure was proven by showing a significant difference in concentration.

Table 3. Summary of analysis of GHB-conjugates and other metabolites in human biological samples from GHB users.

\begin{tabular}{|c|c|c|c|c|c|c|c|}
\hline $\begin{array}{l}\text { Reference } \\
\text { No. }\end{array}$ & Sample & $\begin{array}{l}\text { Sample } \\
\text { Prepara- } \\
\text { tion }\end{array}$ & $\begin{array}{l}\text { Analytical } \\
\text { Platform } \\
\text { (Untargeted } \\
\text { or Targeted) }\end{array}$ & $\begin{array}{l}\text { Treatment } \\
\text { (Administration } \\
\text { Dose, Route, } \\
\text { and No. } \\
\text { of Doses) }\end{array}$ & $\begin{array}{l}\text { Sampling } \\
\text { Time }\end{array}$ & Metabolic Changes & Summary \\
\hline [40] & $\begin{array}{l}\text { Volunteers } \\
(n=3), \\
\text { urine }\end{array}$ & Dilution & $\begin{array}{c}\text { LC-QTOF-MS } \\
\text { (untargeted) }\end{array}$ & $\begin{array}{l}2.25 \mathrm{~g} \mathrm{Xyrem}^{\circledR} \\
\text { (equal to } 1.86 \mathrm{~g} \\
\text { of } \mathrm{GHB} \text { ) or } \\
10 \mathrm{~mL} \\
\text { Somsanit } \\
\text { (equal to } 2 \mathrm{~g} \\
\text { of GHB) }\end{array}$ & $\begin{array}{l}\text { Before and } 72 \mathrm{~h} \\
\text { after } \\
\text { administration }\end{array}$ & $\begin{array}{c}\text { GHB-SUL ( } \uparrow \text { but } \\
\text { detected in non-GHB } \\
\text { users), GHB-GLUC } \\
\text { (fluctuate, lower than } \\
\text { thresholds), } \\
\text { GHB-GLUC } / \beta \text {-citryl } \\
\text { glutamic acid ratio } \\
(\uparrow)\end{array}$ & $\begin{array}{c}\text { Failure of GHB-SUL } \\
\text { and GHB-GLUC as } \\
\text { potent markers for } \\
\text { GHB, } \\
\text { GHB-GLUC/ } \beta \text {-citryl } \\
\text { glutamic acid ratio as } \\
\text { a potential biomarker } \\
\text { for GHB } \\
\text { administration }\end{array}$ \\
\hline [41] & $\begin{array}{l}\text { Healthy } \\
\text { men } \\
(n=20), \\
\text { urine }\end{array}$ & Dilution & $\begin{array}{l}\text { LC-QTOF-MS } \\
\text { (untargeted) }\end{array}$ & $\begin{array}{c}50 \mathrm{mg} / \mathrm{kg} \\
\text { GHB }\left(\text { Xyrem }^{\circledR}\right)\end{array}$ & $\begin{array}{c}4.5 \mathrm{~h} \text { after } \\
\text { administration }\end{array}$ & $\begin{array}{c}\text { Glycolate }(\uparrow) \text {, } \\
\text { succinylcarnitine }(\uparrow) \text {, } \\
\text { GHB-carnitine }(\uparrow) \text {, } \\
\text { GHB-glutamate }(\uparrow) \text {, } \\
\text { GHB-glycine }(\uparrow)\end{array}$ & $\begin{array}{c}\text { Discovery of new } \\
\text { metabolites of GHB } \\
\text { (GHB-carnitine, } \\
\text { GHB-glutamate, and } \\
\text { GHB-glycine) }\end{array}$ \\
\hline
\end{tabular}

LC-QTOF-MS, liquid chromatography-quadrupole-time-of-flight mass spectrometry; $\uparrow$, significantly increased vs. before administration.

\section{Future Directions and Conclusions}

GHB exists as a physiological compound in the human body; it is difficult to distinguish between EnGHB and ExGHB. Because of its rapid metabolism, it is difficult to identify abuse or drug-related crimes by detecting GHB in human biological samples. Recently, a number of studies focusing on metabolites have been conducted in the field of forensic toxicology. Characterizing and quantifying metabolites in organisms has the advantage of not only being able to predict phenotypes but also suggesting potential biomarkers. Therefore, in this review, the study method and proposed metabolites were reviewed, focusing on the study of ExGHB detection using metabolites. Figure 2 shows a schematic representation of the proposed biomarkers identified in metabolomics and metabolism studies following GHB exposure in rats and humans. Despite possible gaps in the metabolic responses between rats and humans, the detection of metabolic alterations in urinary $\mathrm{OA}, \mathrm{AA}$, and PA can help distinguish between GHB-ingesting animals or humans and controls. The potential of GHB conjugates has been investigated in various clinical settings. In studies using rat urine, $\mathrm{OA}$ (citric acid, isocitric acid, cis-aconitic acid, D-2-HG), AA (phenylalanine, glutamic acid, aspartic acid, aspartic acid, methionine), and PA ( $\mathrm{N}^{1}$-acetylspermine, spermine) were proposed as biomarkers to detect ExGHB. In addition, glycolic acid was also proposed as a biomarker in studies using human urine. However, there are many limitations in using these metabolites as biomarkers to determine ExGHB. Urine OA is affected by the subject's health status, nutritional status, vitamin deficiency, and drugs. In particular, mitochondrial dysfunction, which is considered to be one of the causes of chronic 
disease, affects metabolites related to the TCA cycle. In addition, AA is closely related to prediabetes and insulin resistance, so it is suggested as a predictor of type 2 diabetes, while PA is a powerful metabolite that can predict Parkinson's disease. Various other factors, such as physical activity, pharmacological treatment, nutritional interventions, and exposure to other substances also affect the levels of metabolites in biological samples [100]. Significant alterations in the levels of lipid-related metabolites [101-106], tryptophan and other amino acid-related metabolites, and tricarboxylic acid (TCA) cycle components, including malate, aconitate, citrate, fumarate, succinate, and alpha-ketoglutarate [106-112] were observed after endurance exercise.

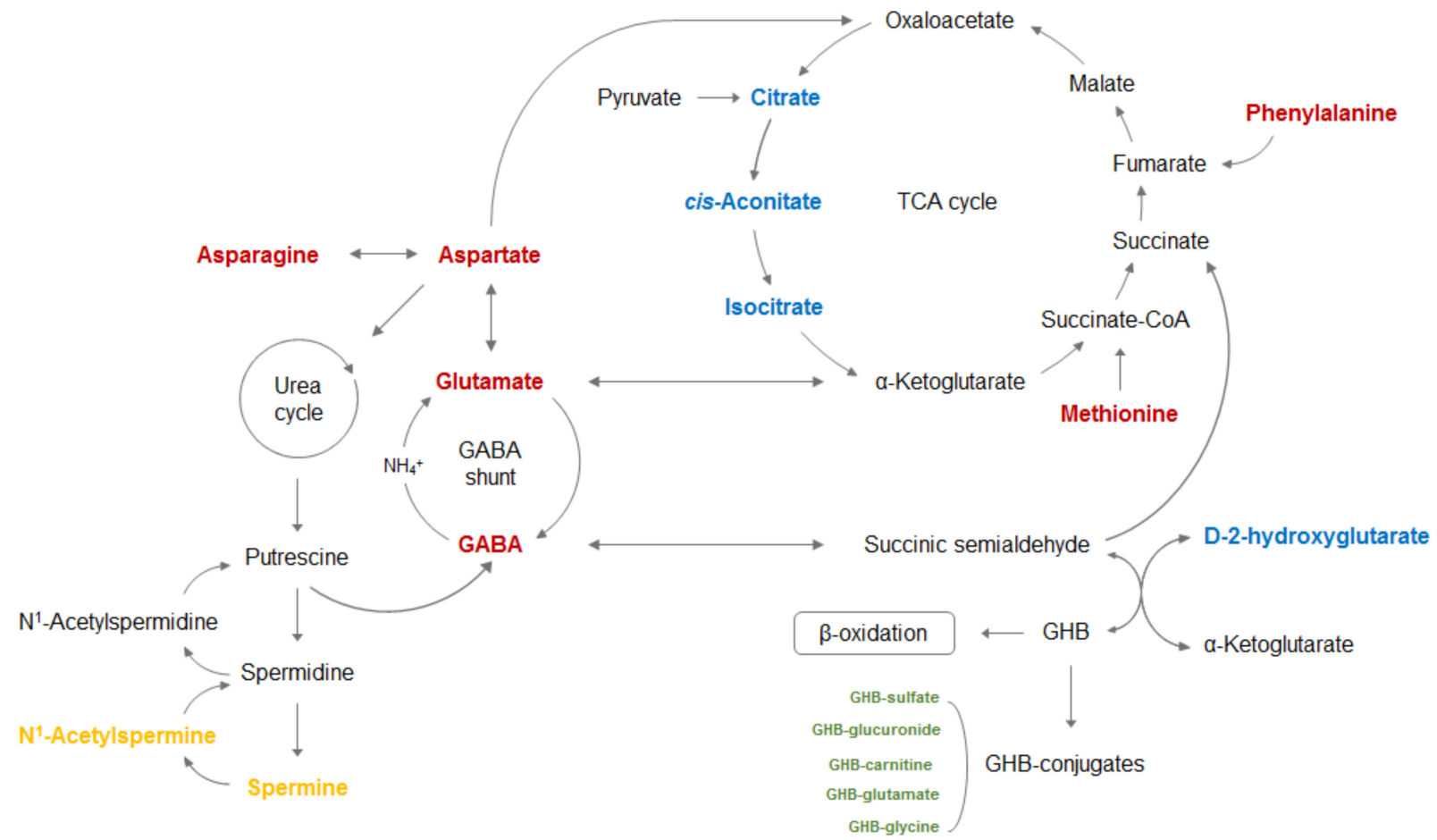

Figure 2. Altered metabolic pathway associated with GHB exposure based on findings from previous studies using rats and humans. Proposed biomarkers are displayed in the following colors (blue color, organic acid; red color, amino acid; yellow color, polyamine; green color, GHB-conjugate).

Therefore, in order to use the metabolites related to the TCA cycle and metabolites related to the urea cycle as biomarkers for ExGHB identification, the changes in GHB metabolism, according to physiological conditions, must be identified. Meanwhile, there is increasing interest in phase-II-metabolites (GHB-GLUC and GHB-SUL), which have a relatively longer half-life and slower removal rate, as compared to GHB. However, there is insufficient evidence to be presented as a biomarker for discriminating GHB exposure, since most previous studies are in the stage of measuring the basal level of phase-II metabolites in urine, nails, and hair in healthy humans. Despite the recent growth in the application of metabolomics to understand the effect of GHB on the metabolic system, there are numerous opportunities for enhancing and expanding the impact of metabolomics in the discovery of biomarkers for GHB exposure. In particular, toxicokinetic investigations of metabolites or metabolite ratios need to be considered to overcome the rapid elimination of GHB. Moreover, GHB-related potential biomarkers proposed in previous studies need to be validated in clinical settings.

Author Contributions: S.L. and Y.S. conceived and designed the review. S.J. and S.K. wrote the manuscript. S.J. and S.K. designed the figures. All authors have read and agreed to the published version of the manuscript. 
Funding: This research was supported by the Basic Science Research Program (NRF-2016R1A6A 1A03011325 and NRF-2018R1D1A1B07048159) through the National Research Foundation (NRF) funded by the Ministry of Education in Korea and by the National Life Safety Emergency Response Research Program (NRF-2019M3E9A1109503) of the NRF funded by the Ministry of Science and ICT in Korea.

Conflicts of Interest: The authors declare that they have no conflict of interest.

\section{References}

1. Califf, R.M. Biomarker definitions and their applications. Exp. Biol. Med. 2018, 243, 213-221. [CrossRef]

2. Cambiaghi, A.; Ferrario, M.; Masseroli, M. Analysis of metabolomic data: Tools, current strategies and future challenges for omics data integration. Brief. Bioinform. 2017, 18, 498-510. [CrossRef]

3. Johnson, C.H.; Ivanisevic, J.; Siuzdak, G. Metabolomics: Beyond biomarkers and towards mechanisms. Nat. Rev. Mol. Cell Biol. 2016, 17, 451-459. [CrossRef]

4. Bujak, R.; Struck-Lewicka, W.; Markuszewski, M.J.; Kaliszan, R. Metabolomics for laboratory diagnostics. J. Pharm. BioMed. Anal. 2015, 113, 108-120. [CrossRef]

5. Kim, M.; Jang, W.J.; Shakya, R.; Choi, B.; Jeong, C.H.; Lee, S. Current Understanding of Methamphetamine-associated metabolic changes revealed by the metabolomics approach. Metabolites 2019, 9, 195. [CrossRef]

6. Choi, B.; Kim, S.P.; Hwang, S.; Hwang, J.; Yang, C.H.; Lee, S. Metabolic characterization in urine and hair from a rat model of methamphetamine self- administration using LC-QTOF-MS-based metabolomics. Metabolomics 2017, 13, 119. [CrossRef]

7. Jang, W.J.; Choi, J.Y.; Park, B.; Seo, J.H.; Seo, Y.H.; Lee, S.; Jeong, C.H. Hair Metabolomics in Animal Studies and Clinical Settings. Molecules 2019, 24, 2195. [CrossRef]

8. Kim, S.; Jang, W.J.; Yu, H.; Kim, J.; Lee, S.K.; Jeong, C.H.; Lee, S. Revealing Metabolic Perturbation Following Heavy Methamphetamine Abuse by Human Hair Metabolomics and Network Analysis. Int. J. Mol. Sci. 2020, 21, 6041. [CrossRef]

9. Kim, S.; Jang, W.J.; Yu, H.; Ryu, I.S.; Jeong, C.H.; Lee, S. Integrated Non-targeted and Targeted Metabolomics Uncovers Dynamic Metabolic Effects during Short-Term Abstinence in Methamphetamine Self-Administering Rats. J. Proteome Res. 2019, 18, 3913-3925. [CrossRef]

10. Nielsen, K.L.; Telving, R.; Andreasen, M.F.; Hasselstrøm, J.B.; Johannsen, M. A Metabolomics Study of Retrospective Forensic Data from Whole Blood Samples of Humans Exposed to 3,4-Methylenedioxymethamphetamine: A New Approach for Identifying Drug Metabolites and Changes in Metabolism Related to Drug Consumption. J. Proteome Res. 2016, 15, 619-627. [CrossRef]

11. Zaitsu, K.; Miyawaki, I.; Bando, K.; Horie, H.; Shima, N.; Katagi, M.; Tatsuno, M.; Bamba, T.; Sato, T.; Ishii, A.; et al. Metabolic profiling of urine and blood plasma in rat models of drug addiction on the basis of morphine, methamphetamine, and cocaineinduced conditioned place preference. Anal. BioAnal. Chem. 2014, 406, 1339-1354. [CrossRef]

12. Alvarez, J.A.; Chong, E.Y.; Walker, D.I.; Chandler, J.D.; Michalski, E.S.; Grossmann, R.E.; Uppal, K.; Li, S.; Frediani, J.K.; Tirouvanziam, R.; et al. Plasma metabolomics in adults with cystic fibrosis during a pulmonary exacerbation: A pilot randomized study of high-dose vitamin D(3) administration. Metabolism 2017, 70, 31-41. [CrossRef]

13. Kamal, R.M.; van Iwaarden, S.; Dijkstra, B.A.; de Jong, C.A. Decision rules for GHB ( $\gamma$-hydroxybutyric acid) detoxification: A vignette study. Drug Alcohol Depend. 2014, 135, 146-151. [CrossRef]

14. Kam, P.C.; Yoong, F.F. Gamma-hydroxybutyric acid: An emerging recreational drug. Anaesthesia 1998, 53, 1195-1198. [CrossRef]

15. Boscolo-Berto, R.; Viel, G.; Montagnese, S.; Raduazzo, D.I.; Ferrara, S.D.; Dauvilliers, Y. Narcolepsy and effectiveness of gammahydroxybutyrate (GHB): A systematic review and meta-analysis of randomized controlled trials. Sleep Med. Rev. 2012, 16, 431-443. [CrossRef]

16. Schep, L.J.; Knudsen, K.; Slaughter, R.J.; Vale, J.A.; Mégarbane, B. The clinical toxicology of $\gamma$-hydroxybutyrate, $\gamma$-butyrolactone and 1,4-butanediol. Clin. Toxicol. (Phila) 2012, 50, 458-470. [CrossRef]

17. Snead, O.C., 3rd; Gibson, K.M. Gamma-hydroxybutyric acid. N. Engl. J. Med. 2005, 352, 2721-2732. [CrossRef]

18. Kapitány-Fövény, M.; Zacher, G.; Posta, J.; Demetrovics, Z. GHB-involved crimes among intoxicated patients. Forensic Sci. Int. 2017, 275, 23-29. [CrossRef]

19. Zvosec, D.L.; Smith, S.W.; Porrata, T.; Strobl, A.Q.; Dyer, J.E. Case series of $226 \gamma$-hydroxybutyrate-associated deaths: Lethal toxicity and trauma. Am. J. Emerg. Med. 2011, 29, 319-332. [CrossRef]

20. de Jong, C.A.; Kamal, R.; Dijkstra, B.A.; de Haan, H.A. Gamma-hydroxybutyrate detoxification by titration and tapering. Eur. Addict. Res. 2012, 18, 40-45. [CrossRef]

21. Dyer, J.E.; Roth, B.; Hyma, B.A. Gamma-hydroxybutyrate withdrawal syndrome. Ann. Emerg. Med. 2001, 37, 147-153. [CrossRef]

22. Craig, K.; Gomez, H.F.; McManus, J.L.; Bania, T.C. Severe gamma-hydroxybutyrate withdrawal: A case report and literature review. J. Emerg. Med. 2000, 18, 65-70. [CrossRef]

23. Weerts, E.M.; Goodwin, A.K.; Griffiths, R.R.; Brown, P.R.; Froestl, W.; Jakobs, C.; Gibson, K.M. Spontaneous and precipitated withdrawal after chronic intragastric administration of gamma-hydroxybutyrate (GHB) in baboons. Psychopharmacology 2005, 179, 678-687. [CrossRef]

24. Caldicott, D.G.; Kuhn, M. Gamma-hydroxybutyrate overdose and physostigmine: Teaching new tricks to an old drug? Ann. Emerg. Med. 2001, 37, 99-102. [CrossRef] 
25. Yates, S.W.; Viera, A.J. Physostigmine in the treatment of gamma-hydroxybutyric acid overdose. Mayo Clin. Proc. 2000, 75, 401-402. [CrossRef]

26. Zvosec, D.L.; Smith, S.W.; Litonjua, R.; Westfal, R.E. Physostigmine for gamma-hydroxybutyrate coma: Inefficacy, adverse events, and review. Clin. Toxicol. 2007, 45, 261-265. [CrossRef]

27. Devoto, P.; Colombo, G.; Cappai, F.; Gessa, G.L. Naloxone antagonizes ethanol- but not gamma-hydroxybutyrate-induced sleep in mice. Eur. J. Pharm. 1994, 252, 321-324. [CrossRef]

28. Lee, D.C.; Satz, W.A.; Dougherty, T.; Greene, T. An investigation of flumazenil to antagonize gamma-hydroxybutyrate intoxication in a murine model. J. Med. Toxicol. 2006, 2, 68-70. [CrossRef]

29. Carai, M.A.; Colombo, G.; Gessa, G.L. Resuscitative effect of a gamma-aminobutyric acid B receptor antagonist on gammahydroxybutyric acid mortality in mice. Ann. Emerg. Med. 2005, 45, 614-619. [CrossRef]

30. Elliott, S. Nonfatal instances of intoxication with gamma-hydroxybutyrate in the United Kingdom. Drug Monit. 2004, 26, 432-440. [CrossRef]

31. Kugelberg, F.C.; Holmgren, A.; Eklund, A.; Jones, A.W. Forensic toxicology findings in deaths involving gamma-hydroxybutyrate. Int. J. Leg. Med. 2010, 124, 1-6. [CrossRef]

32. Lee, H.-S.; Seo, C.; Kim, Y.-A.; Park, M.; Choi, B.; Ji, M.; Lee, S.; Paik, M.-J. Metabolomic study of polyamines in rat urine following intraperitoneal injection of $\gamma$-hydroxybutyric acid. Metabolomics 2019, 15, 58. [CrossRef]

33. Palomino-Schätzlein, M.; Wang, Y.; Brailsford, A.D.; Parella, T.; Cowan, D.A.; Legido-Quigley, C.; Pérez-Trujillo, M. Direct Monitoring of Exogenous $\gamma$-Hydroxybutyric Acid in Body Fluids by NMR Spectroscopy. Anal. Chem. 2017, 89, 8343-8350. [CrossRef]

34. Seo, C.; Na, M.; Jang, J.; Park, M.; Choi, B.; Lee, S.; Paik, M.-J. Monitoring of altered amino acid metabolic pattern in rat urine following intraperitoneal injection with $\gamma$-hydroxybutyric acid. Metabolomics 2018, 14, 111. [CrossRef]

35. Hanisch, S.; Stachel, N.; Skopp, G. A potential new metabolite of gamma-hydroxybutyrate: Sulfonated gamma-hydroxybutyric acid. Int. J. Leg. Med. 2016, 130, 411-414. [CrossRef]

36. Petersen, I.N.; Tortzen, C.; Kristensen, J.L.; Pedersen, D.S.; Breindahl, T. Identification of a new metabolite of GHB: Gammahydroxybutyric acid glucuronide. J. Anal. Toxicol. 2013, 37, 291-297. [CrossRef]

37. Pascali, J.P.; Fais, P.; Vaiano, F.; Ciolini, A.; Bertol, E. Zwitterionic HILIC stationary phase as a valuable alternative in separative techniques: Application to the analysis of gamma-hydroxybutyric acid and its metabolite in hair. J. Chromatogr. B Anal. Technol. BioMed. Life Sci. 2019, 1134-1135, 121876. [CrossRef]

38. Dias, A.S.; Castro, A.L.; Melo, P.; Tarelho, S.; Domingues, P.; Franco, J.M. A fast method for GHB-GLUC quantitation in whole blood by GC-MS/MS (TQD) for forensic purposes. J. Pharm. BioMed. Anal. 2018, 150, 107-111. [CrossRef]

39. Busardò, F.P.; Gottardi, M.; Tini, A.; Mortali, C.; Giorgetti, R.; Pichini, S. Ultra-High-Performance Liquid Chromatography Tandem Mass Spectrometry Assay for Determination of Endogenous GHB and GHB-Glucuronide in Nails. Molecules 2018, $23,2686$. [CrossRef]

40. Piper, T.; Mehling, L.M.; Spottke, A.; Heidbreder, A.; Young, P.; Madea, B.; Hess, C.; Schänzer, W.; Thevis, M. Potential of GHB phase-II-metabolites to complement current approaches in GHB post administration detection. Forensic Sci. Int. 2017, 279, 157-164. [CrossRef]

41. Steuer, A.E.; Raeber, J.; Steuer, C.; Boxler, M.I.; Dornbierer, D.A.; Bosch, O.G.; Quednow, B.B.; Seifritz, E.; Kraemer, T. Identification of new urinary gamma-hydroxybutyric acid markers applying untargeted metabolomics analysis following placebo-controlled administration to humans. Drug Test Anal. 2019, 11, 813-823. [CrossRef]

42. Seo, C.; Park, M.; Choi, B.; Lee, S.; Paik, M.-J. Metabolomic analysis of urinary organic acids following intraperitoneal injection with $\gamma$-hydroxybutyric acid in rats. Metabolomics 2016, 12, 190. [CrossRef]

43. Tunnicliff, G. Sites of action of gamma-hydroxybutyrate (GHB)-a neuroactive drug with abuse potential. J. Toxicol. Clin. Toxicol. 1997, 35, 581-590. [CrossRef]

44. Wong, C.G.; Chan, K.F.; Gibson, K.M.; Snead, O.C. Gamma-hydroxybutyric acid: Neurobiology and toxicology of a recreational drug. Toxicol. Rev. 2004, 23, 3-20. [CrossRef]

45. Mamelak, M. Gammahydroxybutyrate: An endogenous regulator of energy metabolism. NeuroSci. Biobehav. Rev. 1989, 13, 187-198. [CrossRef]

46. Maitre, M. The gamma-hydroxybutyrate signalling system in brain: Organization and functional implications. Prog. NeuroBiol. 1997, 51, 337-361. [CrossRef]

47. Hogema, B.M.; Gupta, M.; Senephansiri, H.; Burlingame, T.G.; Taylor, M.; Jakobs, C.; Schutgens, R.B.; Froestl, W.; Snead, O.C.; Diaz-Arrastia, R.; et al. Pharmacologic rescue of lethal seizures in mice deficient in succinate semialdehyde dehydrogenase. Nat. Genet. 2001, 29, 212-216. [CrossRef]

48. Andresen, H.; Aydin, B.E.; Mueller, A.; Iwersen-Bergmann, S. An overview of gamma-hydroxybutyric acid: Pharmacodynamics, pharmacokinetics, toxic effects, addiction, analytical methods, and interpretation of results. Drug Test Anal. 2011, 3, 560-568. [CrossRef]

49. LeBeau, M.A.; Miller, M.L.; Levine, B. Effect of storage temperature on endogenous GHB levels in urine. Forensic Sci. Int. 2001, 119, 161-167. [CrossRef]

50. Brenneisen, R.; Elsohly, M.A.; Murphy, T.P.; Passarelli, J.; Russmann, S.; Salamone, S.J.; Watson, D.E. Pharmacokinetics and excretion of gamma-hydroxybutyrate (GHB) in healthy subjects. J. Anal. Toxicol. 2004, 28, 625-630. [CrossRef] 
51. Kintz, P.; Goullé, J.P.; Cirimele, V.; Ludes, B. Window of detection of gamma-hydroxybutyrate in blood and saliva. Clin. Chem. 2001, 47, 2033-2034. [CrossRef]

52. Haller, C.; Thai, D.; Jacob, P., 3rd; Dyer, J.E. GHB urine concentrations after single-dose administration in humans. J. Anal. Toxicol. 2006, 30, 360-364. [CrossRef]

53. Busardò, F.P.; Pichini, S.; Zaami, S.; Pacifici, R.; Kintz, P. Hair testing of GHB: An everlasting issue in forensic toxicology. Clin. Chem. Lab. Med. 2018, 56, 198-208. [CrossRef]

54. Bosman, I.J.; Lusthof, K.J. Forensic cases involving the use of GHB in The Netherlands. Forensic Sci. Int. 2003, 133, 17-21. [CrossRef]

55. Elian, A.A. Determination of endogenous gamma-hydroxybutyric acid (GHB) levels in antemortem urine and blood. Forensic Sci. Int. 2002, 128, 120-122. [CrossRef]

56. Yeatman, D.T.; Reid, K. A study of urinary endogenous gamma-hydroxybutyrate (GHB) levels. J. Anal. Toxicol. 2003, 27, 40-42. [CrossRef]

57. Steinecke, H. Beitrag zur Bewertung von Gamma-Hydroxybuttersa"ure (GHB)-Konzentrationen im Blut lebender Personen sowie in postmortalen Blutproben. ToxiChem. Krimtech. 2007, 74, 150-154.

58. Crookes, C.E.; Faulds, M.C.; Forrest, A.R.; Galloway, J.H. A reference range for endogenous gamma-hydroxybutyrate in urine by gas chromatography-mass spectrometry. J. Anal. Toxicol. 2004, 28, 644-649. [CrossRef]

59. McCusker, R.R.; Paget-Wilkes, H.; Chronister, C.W.; Goldberger, B.A. Analysis of gamma-hydroxybutyrate (GHB) in urine by gas chromatography-mass spectrometry. J. Anal. Toxicol. 1999, 23, 301-305. [CrossRef]

60. Kavanagh, P.V.; Kenny, P.; Feely, J. The urinary excretion of gamma-hydroxybutyric acid in man. J. Pharm. Pharm. 2001, 53, 399-402. [CrossRef]

61. Andresen, H.; Sprys, N.; Schmoldt, A.; Mueller, A.; Iwersen-Bergmann, S. Gamma-hydroxybutyrate in urine and serum: Additional data supporting current cut-off recommendations. Forensic Sci. Int. 2010, 200, 93-99. [CrossRef]

62. Kang, S.; Oh, S.M.; Chung, K.H.; Lee, S. A surrogate analyte-based LC-MS/MS method for the determination of $\gamma$-hydroxybutyrate (GHB) in human urine and variation of endogenous urinary concentrations of GHB. J. Pharm. BioMed. Anal. 2014, 98, 193-200. [CrossRef]

63. White, C.M. Pharmacologic, pharmacokinetic, and clinical assessment of illicitly used gamma-hydroxybutyrate. J. Clin. Pharm. 2017, 57, 33-39. [CrossRef]

64. Busardo, F.P.; Kyriakou, C. GHB in biological specimens: Which cut-off levels should be taken into consideration in forensic toxicological investigation? Recent Pat. Biotechnol. 2014, 8, 206-214. [CrossRef]

65. Vogel, K.R.; Ainslie, G.R.; Walters, D.C.; McConnell, A.; Dhamne, S.C.; Rotenberg, A.; Roullet, J.B.; Gibson, K.M. Succinic semialdehyde dehydrogenase deficiency, a disorder of GABA metabolism: An update on pharmacological and enzyme-replacement therapeutic strategies. J. Inherit. Metab. Dis. 2018, 41, 699-708. [CrossRef]

66. DiBacco, M.L.; Roullet, J.B.; Kapur, K.; Brown, M.N.; Walters, D.C.; Gibson, K.M.; Pearl, P.L. Age-related phenotype and biomarker changes in SSADH deficiency. Ann. Clin. Transl. Neurol. 2019, 6, 114-120. [CrossRef]

67. Beránková, K.; Mutnanská, K.; Balíková, M. Gamma-hydroxybutyric acid stability and formation in blood and urine. Forensic Sci. Int. 2006, 161, 158-162. [CrossRef]

68. Brailsford, A.D.; Cowan, D.A.; Kicman, A.T. Urinary $\gamma$-hydroxybutyrate concentrations in 1126 female subjects. J. Anal. Toxicol. 2010, 34, 555-561. [CrossRef]

69. Abanades, S.; Farré, M.; Segura, M.; Pichini, S.; Pastor, A.; Pacifici, R.; Pellegrini, M.; de la Torre, R. Disposition of gammahydroxybutyric acid in conventional and nonconventional biologic fluids after single drug administration: Issues in methodology and drug monitoring. Drug Monit. 2007, 29, 64-70. [CrossRef]

70. De Paoli, G.; Walker, K.M.; Pounder, D.J. Endogenous $\gamma$-hydroxybutyric acid concentrations in saliva determined by gas chromatography-mass spectrometry. J. Anal. Toxicol. 2011, 35, 148-152. [CrossRef]

71. Castro, A.L.; Dias, M.; Reis, F.; Teixeira, H.M. Gamma-hydroxybutyric acid endogenous production and post-mortem behaviorThe importance of different biological matrices, cut-off reference values, sample collection and storage conditions. J. Forensic Leg Med. 2014, 27, 17-24. [CrossRef]

72. Elliot, S. The presence of gamma-hydroxybutyric acid (GHB) in postmortem biological fluids. J. Anal. Toxicol. 2001, 25, 152. [CrossRef]

73. Kintz, P.; Villain, M.; Cirimele, V.; Ludes, B. GHB in postmortem toxicology. Discrimination between endogenous production from exposure using multiple specimens. Forensic Sci. Int. 2004, 143, 177-181. [CrossRef]

74. Sadones, N.; Capiau, S.; De Kesel, P.M.; Lambert, W.E.; Stove, C. Spot them in the spot: Analysis of abused substances using dried blood spots. Bioanalysis 2014, 6, 2211-2227. [CrossRef]

75. Stove, C.P.; Ingels, A.S.; De Kesel, P.M.; Lambert, W.E. Dried blood spots in toxicology: From the cradle to the grave? Crit. Rev. Toxicol. 2012, 42, 230-243. [CrossRef]

76. Busardò, F.P.; Vergallo, G.M.; Plazzi, G. GHB Pharmacology and Toxicology: From Metabolism and Pharmacokinetics to Applications: In Clinical and Forensic Toxicology. Curr. Drug Metab. 2018, 19, 1054-1055. [CrossRef]

77. Kintz, P.A. Novel Approach to Document Single Exposure to GHB: Hair Analysis after Sweat Contamination. J. Anal. Toxicol. 2016, 40, 563-564. [CrossRef] 
78. Wang, Y.; Zhang, W.; Yuan, J.; Shen, J. Differences in cytocompatibility between collagen, gelatin and keratin. Mater. Sci. Eng. C Mater. Biol. Appl. 2016, 59, 30-34. [CrossRef]

79. Shima, N.; Miki, A.; Kamata, T.; Katagi, M.; Tsuchihashi, H. Urinary endogenous concentrations of GHB and its isomers in healthy humans and diabetics. Forensic Sci. Int. 2005, 149, 171-179. [CrossRef]

80. LeBeau, M.A.; Montgomery, M.A.; Morris-Kukoski, C.; Schaff, J.E.; Deakin, A.; Levine, B. A comprehensive study on the variations in urinary concentrations of endogenous gamma-hydroxybutyrate (GHB). J. Anal. Toxicol. 2006, 30, 98-105. [CrossRef]

81. Raknes, G.; Aronsen, L.; Fuskevåg, O.M. Urinary concentrations of gamma-hydroxybutyric acid and related compounds in pregnancy. J. Anal. Toxicol. 2010, 34, 394-399. [CrossRef]

82. Brailsford, A.D.; Cowan, D.A.; Kicman, A.T. Pharmacokinetic properties of $\gamma$-hydroxybutyrate (GHB) in whole blood, serum, and urine. J. Anal. Toxicol. 2012, 36, 88-95. [CrossRef]

83. Dahl, S.R.; Olsen, K.M.; Strand, D.H. Determination of $\gamma$-hydroxybutyrate (GHB), $\beta$-hydroxybutyrate (BHB), pregabalin, 1,4butane-diol (1,4BD) and $\gamma$-butyrolactone (GBL) in whole blood and urine samples by UPLC-MSMS. J. Chromatogr. B Anal. Technol. BioMed. Life Sci. 2012, 885-886, 37-42. [CrossRef]

84. Johansen, S.S.; Windberg, C.N. Simultaneous determination of $\gamma$-Hydroxybutyrate (GHB) and its analogues (GBL, 1.4-BD, GVL) in whole blood and urine by liquid chromatography coupled to tandem mass spectrometry. J. Anal. Toxicol. 2011, 35, 8-14. [CrossRef]

85. Fjeld, B.; Burns, M.L.; Karinen, R.; Larssen, B.; Smith-Kielland, A.; Vindenes, V. Long-term stability of GHB in post-mortem samples and samples from living persons, stored at $-20^{\circ} \mathrm{C}$, using fluoride preservatives. Forensic Sci. Int. 2012, $222,47-51$. [CrossRef]

86. Struys, E.A.; Verhoeven, N.M.; Jansen, E.E.; Ten Brink, H.J.; Gupta, M.; Burlingame, T.G.; Quang, L.S.; Maher, T.; Rinaldo, P.; Snead, O.C.; et al. Metabolism of gamma-hydroxybutyrate to d-2-hydroxyglutarate in mammals: Further evidence for d-2-hydroxyglutarate transhydrogenase. Metabolism 2006, 55, 353-358. [CrossRef]

87. Liebich, H.M. Gas chromatographic profiling of ketone bodies and organic acids in diabetes. J. Chromatogr. 1986, 379, 347-366. [CrossRef]

88. Hur, H.; Paik, M.J.; Xuan, Y.; Nguyen, D.T.; Ham, I.H.; Yun, J.; Cho, Y.K.; Lee, G.; Han, S.U. Quantitative measurement of organic acids in tissues from gastric cancer patients indicates increased glucose metabolism in gastric cancer. PLoS ONE 2014, 9, e98581. [CrossRef]

89. Kuhara, T. Gas chromatographic-mass spectrometric urinary metabolome analysis to study mutations of inborn errors of metabolism. Mass Spectrom. Rev. 2005, 24, 814-827. [CrossRef]

90. Paik, M.J.; Lee, H.J.; Kim, K.R. Simultaneous retention index analysis of urinary amino acids and carboxylic acids for graphic recognition of abnormal state. J. Chromatogr. B Anal. Technol. BioMed. Life Sci. 2005, 821, 94-104. [CrossRef]

91. Kim, J.-W.; Lee, G.; Moon, S.-M.; Park, M.-J.; Hong, S.K.; Ahn, Y.-H.; Kim, K.-R.; Paik, M.-J. Metabolomic screening and star pattern recognition by urinary amino acid profile analysis from bladder cancer patients. Metabolomics 2010, 6, 202-206. [CrossRef]

92. Miller-Fleming, L.; Olin-Sandoval, V.; Campbell, K.; Ralser, M. Remaining Mysteries of Molecular Biology: The Role of Polyamines in the Cell. J. Mol. Biol. 2015, 427, 3389-3406. [CrossRef]

93. Seiler, N. Catabolism of polyamines. Amino Acids 2004, 26, 217-233. [CrossRef]

94. Tabor, C.W.; Tabor, H. Polyamines. Annu. Rev. BioChem. 1984, 53, 749-790. [CrossRef]

95. Gross, J.A.; Turecki, G. Suicide and the polyamine system. CNS Neurol. Disord. Drug Targets 2013, 12, 980-988. [CrossRef]

96. Nowotarski, S.L.; Woster, P.M.; Casero, R.A., Jr. Polyamines and cancer: Implications for chemotherapy and chemoprevention. Expert Rev. Mol. Med. 2013, 15, e3. [CrossRef]

97. Paik, M.J.; Kim, H.S.; Lee, Y.S.; Choi, H.D.; Pack, J.K.; Kim, N.; Ahn, Y.H. Metabolomic study of urinary polyamines in rat exposed to $915 \mathrm{MHz}$ radiofrequency identification signal. Amino Acids 2016, 48, 213-217. [CrossRef]

98. Mehling, L.M.; Wang, X.; Johansen, S.S.; Spottke, A.; Heidbreder, A.; Young, P.; Madea, B.; Hess, C. Determination of GHB and GHB- $\beta$-O-glucuronide in hair of three narcoleptic patients-Comparison between single and chronic GHB exposure. Forensic Sci. Int. 2017, 278, e8-e13. [CrossRef]

99. Mehling, L.M.; Piper, T.; Spottke, A.; Heidbreder, A.; Young, P.; Madea, B.; Thevis, M.; Hess, C. GHB-O- $\beta$-glucuronide in blood and urine is not a suitable tool for the extension of the detection window after GHB intake. Forensic Toxicol. 2017, 35, 263-274. [CrossRef]

100. Sakaguchi, C.A.; Nieman, D.C.; Signini, E.F.; Abreu, R.M.; Catai, A.M. Metabolomics-Based Studies Assessing Exercise-Induced Alterations of the Human Metabolome: A Systematic Review. Metabolites 2019, 9, 164. [CrossRef]

101. Nieman, D.C.; Gillitt, N.D.; Sha, W.; Meaney, M.P.; John, C.; Pappan, K.L.; Kinchen, J.M. Metabolomics-Based Analysis of Banana and Pear Ingestion on Exercise Performance and Recovery. J. Proteome Res. 2015, 14, 5367-5377. [CrossRef]

102. Nieman, D.C.; Scherr, J.; Luo, B.; Meaney, M.P.; Dréau, D.; Sha, W.; Dew, D.A.; Henson, D.A.; Pappan, K.L. Influence of pistachios on performance and exercise-induced inflammation, oxidative stress, immune dysfunction, and metabolite shifts in cyclists: A randomized, crossover trial. PLoS ONE 2014, 9, e113725. [CrossRef]

103. Davison, G.; Vinaixa, M.; McGovern, R.; Beltran, A.; Novials, A.; Correig, X.; McClean, C. Metabolomic response to acute hypoxic exercise and recovery in adult males. Front. Physiol. 2018, 9, 1682. [CrossRef] 
104. Lehmann, R.; Zhao, X.; Weigert, C.; Simon, P.; Fehrenbach, E.; Fritsche, J.; Machann, J.; Schick, F.; Wang, J.; Hoene, M.; et al. Medium chain acylcarnitines dominate the metabolite pattern in humans under moderate intensity exercise and support lipid oxidation. PLoS ONE 2010, 5, e11519. [CrossRef]

105. Nieman, D.C.; Gillitt, N.D.; Knab, A.M.; Shanely, R.A.; Pappan, K.L.; Jin, F.; Lila, M.A. Influence of a polyphenol-enriched protein powder on exercise-induced inflammation and oxidative stress in athletes: A randomized trial using a metabolomics approach. PLoS ONE 2013, 8, e72215. [CrossRef]

106. Manaf, F.A.; Lawler, N.; Peiffer, J.J.; Maker, G.L.; Boyce, M.C.; Fairchild, T.J.; Broadhurst, D. Characterizing the plasma metabolome during and following a maximal exercise cycling test. J. Appl. Physiol. 2018, 125, 1193-1203. [CrossRef]

107. Lewis, G.D.; Farrell, L.; Wood, M.J.; Martinovic, M.; Arany, Z.; Rowe, G.C.; Souza, A.; Cheng, S.; McCabe, E.L.; Yang, E.; et al. Metabolic signatures of exercise in human plasma. Sci. Transl. Med. 2010, 2, 33ra37. [CrossRef]

108. Knab, A.M.; Nieman, D.C.; Gillitt, N.D.; Shanely, R.A.; Cialdella-Kam, L.; Henson, D.A.; Sha, W. Effects of a flavonoid-rich juice on inflammation, oxidative stress, and immunity in elite swimmers: A metabolomics-based approach. Int. J. Sport Nutr. Exerc. Metab. 2013, 23, 150-160. [CrossRef]

109. Messier, F.M.; Le Moyec, L.; Santi, C.; Gaston, A.F.; Triba, M.N.; Roca, E.; Durand, F. The impact of moderate altitude on exercise metabolism in recreational sportsmen: A nuclear magnetic resonance metabolomic approach. Appl. Physiol. Nutr. Metab. 2017, 42, 1135-1141. [CrossRef]

110. Nieman, D.C.; Shanely, R.A.; Gillitt, N.D.; Pappan, K.L.; Lila, M.A. Serum metabolic signatures induced by a three-day intensified exercise period persist after $14 \mathrm{~h}$ of recovery in runners. J. Proteome Res. 2013, 12, 4577-4584. [CrossRef]

111. Stander, Z.; Luies, L.; Mienie, L.J.; Keane, K.M.; Howatson, G.; Clifford, T.; Stevenson, E.J.; Loots, D.T. The altered human serum metabolome induced by a marathon. Metabolomics 2018, 14, 150. [CrossRef]

112. Nieman, D.C.; Gillitt, N.D.; Sha, W. Identification of a select metabolite panel for measuring metabolic perturbation in response to heavy exertion. Metabolomics 2018, 14, 147. [CrossRef] 